\title{
Influenza D Virus Infection in Feral Swine Populations, United States
}

\author{
Lucas Ferguson, ${ }^{1}$ Kaijian Luo, ${ }^{1}$ Alicia K. Olivier, Fred L. Cunningham, \\ Sherry Blackmon, Katie Hanson-Dorr, Hailiang Sun, ${ }^{2}$ John Baroch, Mark W. Lutman, \\ Bianca Quade, William Epperson, Richard Webby, Thomas J. DeLiberto, Xiu-Feng Wan
}

Influenza D virus (IDV) has been identified in domestic cattle, swine, camelid, and small ruminant populations across North America, Europe, Asia, South America, and Africa. Our study investigated seroprevalence and transmissibility of IDV in feral swine. During 2012-2013, we evaluated feral swine populations in 4 US states; of 256 swine tested, 57 (19.1\%) were IDV seropositive. Among 96 archived influenza A virus-seropositive feral swine samples collected from 16 US states during 2010-2013, 41 (42.7\%) were IDV seropositive. Infection studies demonstrated that IDV-inoculated feral swine shed virus $3-5$ days postinoculation and seroconverted at 21 days postinoculation; $50 \%$ of in-contact naive feral swine shed virus, seroconverted, or both. Immunohistochemical staining showed viral antigen within epithelial cells of the respiratory tract, including trachea, soft palate, and lungs. Our findings suggest that feral swine might serve an important role in the ecology of IDV.

$I^{\text {nom }}$ nfluenza D virus (IDV), first isolated in 2011 from a domestic pig with influenza-like symptoms, has genomic similarity to influenza $\mathrm{C}$ virus (ICV) (1). IDV has 7 genomic RNA segments like ICV but exhibits a broader cellular and host tropism than ICV (1), which might be attributable to IDV's open receptor-binding cavity (2). Evidence suggests that IDV circulates in domestic animals, including swine, cattle, camelids, and small ruminants, throughout North America, Asia, Africa, and South America (1,3-15). Among these species, cattle are proposed to be the natural reservoir of IDV $(13,15)$. Susceptibility and seroprevalence of IDV in domestic and wild animal species is largely unknown.

Author affiliations: Mississippi State University, Starkville, Mississippi, USA (L. Ferguson, K. Luo, A.K. Olivier, S. Blackmon, H. Sun, B. Quade, W. Epperson, X.-F. Wan); South China Agricultural University, Guangzhou, China (K. Luo); US Department of Agriculture, Starkville (F.L. Cunningham, K. Hanson-Dorr); US Department of Agriculture, Fort Collins, Colorado, USA (J. Baroch, M.W. Lutman, T.J. DeLiberto); St. Jude Children's Research Hospital, Memphis, Tennessee, USA (R. Webby)

DOI: https://doi.org/10.3201/eid2406.172102
Swine were introduced into what is now the United States in the 15th century. Since that time, populations of free-ranging swine have spread to $\approx 40$ states. These swine are escaped domestic animals, imported wild boar, or hybrids of the two, and they now number $\approx 5$ million (Figure 1, panel A) (16-19). Feral swine transmit diseases that are swine-specific (feral and domestic) as well as diseases that can be transmitted to domestic species (cattle, sheep, goats, horses, and dogs) and wild mammals; some of the more important diseases include porcine circovirus-2, pseudorabies virus, Brucella suis, and influenza A viruses (IAVs) as well as vesicular diseases $(16,17,20-25)$. Feral swine have been shown to have contact with domestic swine in transitional and commercial settings $(17,20)$. Moreover, feral swine also frequently interact with free-ranging cattle near shared water sources (16). Of particular concern, feral swine populations are increasing and pose potential threats to domestic swine and human public health (26).

Little is known regarding seroprevalence of IDV in feral swine. In this study, we conducted serologic surveillance to estimate seroprevalence of IDV in the feral swine population in the United States. We also conducted infection experiments to determine the pathogenesis and transmission of IDV in feral swine.

\section{Materials and Methods}

\section{Viruses}

We used influenza viruses D/bovine/C00046N/Mississip$\mathrm{pi} / 2014$ virus $(\mathrm{D} / 46 \mathrm{~N})$ and $\mathrm{D} /$ bovine/C00013N/Mississip$\mathrm{pi} / 2014$ virus $(\mathrm{D} / 13 \mathrm{~N})$. Before use, the viruses were isolated and passaged twice in HRT-18G cells (American Type Culture Collection, Manassas, VA, USA) with Opti-MEM supplemented with $1 \times$ Pen Strep and $12.5 \times 7.5 \%$ bovine serum albumin (GIBCO Life Technologies, Carlsbad, CA, USA) and 1:2000 $N$-tosyl-L-phenylalanine chloromethyl ketone-Trypsin (Sigma-Aldrich, St. Louis, MO, USA).

${ }^{1}$ These authors contributed equally to this article.

${ }^{2}$ Current affiliation: South China Agricultural University, Guangzhou, China. 

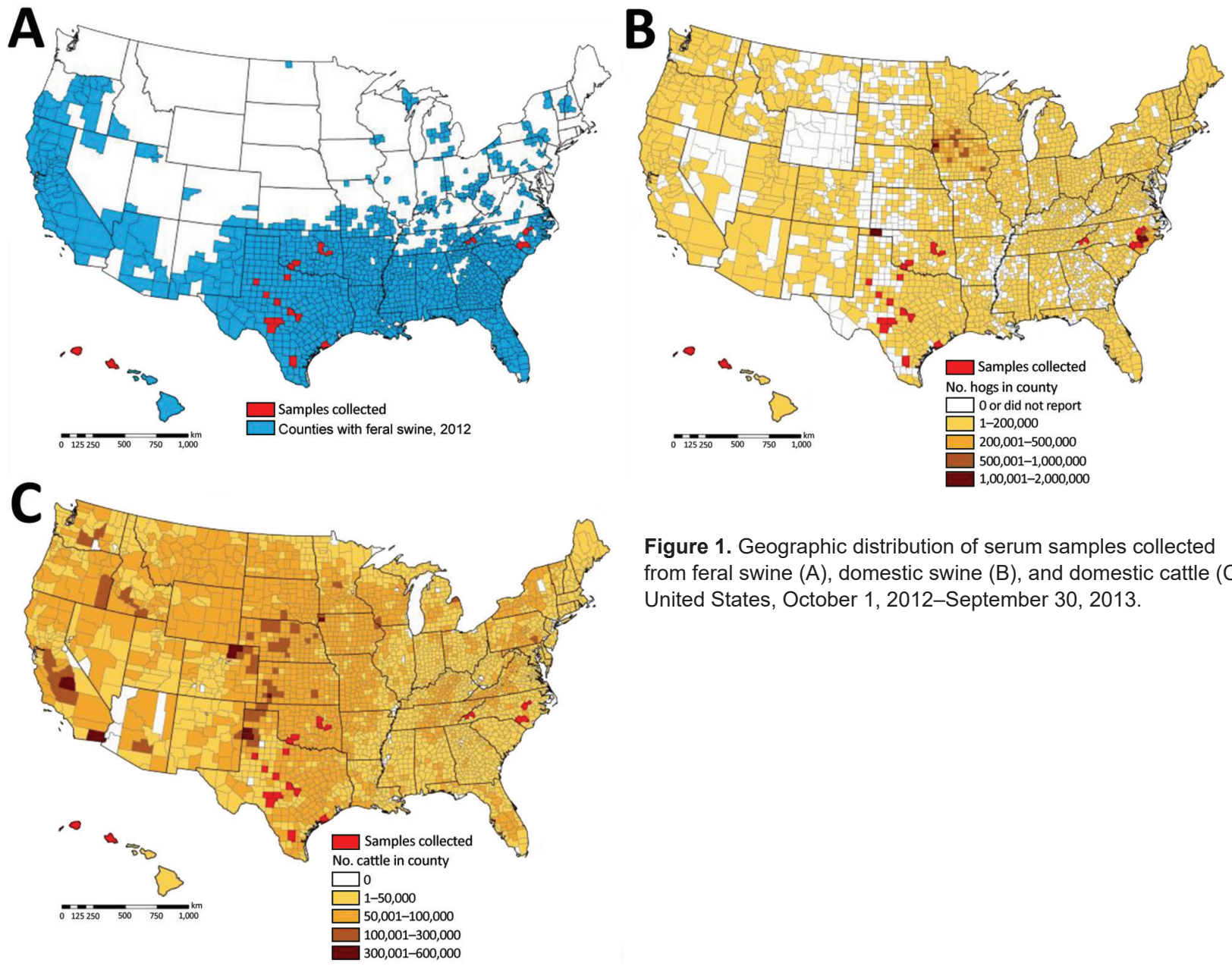

Figure 1. Geographic distribution of serum samples collected from feral swine (A), domestic swine (B), and domestic cattle (C), United States, October 1, 2012-September 30, 2013.

\section{Serum Samples}

A total of 256 convenient serum samples were available from a collection of feral swine serum archived by the US Department of Agriculture's National Wildlife Research Center. The 256 samples constituted feral swine serum samples collected during October 1, 2012-September 30, 2013, in 4 US states: Hawaii ( $\mathrm{n}=73$ samples), North Carolina $(n=64)$, Oklahoma $(n=49)$, and Texas $(n=70)$ (Table 1). North Carolina, Oklahoma, and Texas have large domestic swine populations; Texas and Oklahoma have large cattle populations; and Hawaii, Oklahoma, and Texas have large feral swine populations. Of the 256 serum samples, 118 were from male feral swine, 135 were from female feral swine, and 3 were from feral swine of unknown sex; in addition, 32 of the samples were from juveniles ( $<2$ mo of age), 43 from subadults (2-12 mo of age), and 181 from adults ( $>1$ y of age) (Table 2 ).

Previous studies have suggested that feral swine have been exposed to IAV $(24,25)$. To determine whether feral swine could have been exposed to both IDV and IAV, we identified 96 IAV-seropositive samples. Of the total 256 samples we described, 13 were IAV seropositive and were included in the IAV-seropositive sample set. We selected 83 additional convenient serum samples collected during October 1, 2012-September 30, 2013, from archived feral swine serum samples that had been previously determined to be IAV seropositive using the IDEXX AI MultiS-Screen Ab Test (IDEXX, Westbrook, ME, USA) (9,10). We sampled these 96 IAV-seropositive samples from 16 US states: Alabama ( $\mathrm{n}=7$ samples), Arizona $(\mathrm{n}=1)$, California $(\mathrm{n}=5)$, Florida $(n=6)$, Georgia $(n=8)$, Hawaii $(n=4)$, Illinois $(n=$ 2), Kansas ( $n=5)$, Louisiana $(n=2)$, Missouri $(n=1)$, North Carolina $(n=8)$, New Mexico $(n=1)$, Oklahoma $(n=9)$, South Carolina $(n=1)$, Tennessee $(n=2)$, and Texas $(n=34)$.

\section{Hemagglutination Assays}

We performed hemagglutination (HA) and HA inhibition (HAI) assays as previously described (11). In brief, we treated serum samples with receptor-destroying enzyme (Denka Seiken Co., Tokyo, Japan) at $37^{\circ} \mathrm{C}$ for $\geq 18 \mathrm{hr}$, followed by heat inactivation at $55^{\circ} \mathrm{C}$ for $30 \mathrm{~min}$. We diluted inactivated serum to a final concentration of $1: 10$ 
Table 1. Seroprevalence of influenza D virus among 256 feral swine, by state, United States, October 1, 2012-September 30, 2013*

\begin{tabular}{|c|c|c|c|c|c|}
\hline \multirow[b]{2}{*}{ State, no. samples } & \multicolumn{2}{|c|}{$\mathrm{D} / 13 \mathrm{~N}$} & \multicolumn{2}{|c|}{$\mathrm{D} / 46 \mathrm{~N}$} & \multirow[b]{2}{*}{$\begin{array}{c}\text { Total seropositive } \\
\text { swine, no. }(\%)\end{array}$} \\
\hline & $\begin{array}{c}\text { Seropositive swine, } \\
\text { no. (\%) }\end{array}$ & GMT (range) & $\begin{array}{c}\text { Seropositive swine, } \\
\text { no. }(\%)\end{array}$ & GMT (range) & \\
\hline Hawaii, $n=73$ & $11(16.4)$ & $53.4(1: 40-1: 80)$ & $4(5.5)$ & $67.3(1: 40-1: 80)$ & $15(20.5)$ \\
\hline North Carolina, $n=64$ & $4(6.3)$ & $67.3(1: 40-1: 160)$ & $3(4.7)$ & $40(1: 40-1: 40)$ & $5(7.8)$ \\
\hline Oklahoma, $n=49$ & $13(26.5)$ & $49.5(1: 40-1: 80)$ & $3(6.1)$ & $50.4(1: 40-1: 80)$ & $14(28.6)$ \\
\hline Texas, $\mathrm{n}=70$ & $10(14.3)$ & $85.7(1: 40-1: 160)$ & $8(11.4)$ & $63.5(1: 40-1: 160)$ & $15(21.4)$ \\
\hline
\end{tabular}

with $1 \times$ phosphate-buffered saline. We added turkey red blood cells to the serum (concentration $1: 20$ ) at $4{ }^{\circ} \mathrm{C}$ for 30 min and then centrifuged the serum at $13,000 \mathrm{rpm}$ for 1 min to pellet the red blood cells. We conducted the HA and HAI assays with $0.5 \%$ turkey red blood cells at $4{ }^{\circ} \mathrm{C}$ against a testing IDV; we considered samples with an HAI titer $\geq 1: 40$ as IDV seropositive. We tested all serum samples against influenza $\mathrm{D} / 46 \mathrm{~N}$ and $\mathrm{D} / 13 \mathrm{~N}$.

\section{Infection Experiments}

We trapped a total of 26 feral swine over the course of 100 trap nights in Mississippi and transported them to the US Department of Agriculture's Mississippi Field Station under state permits (nos. 894, 896, and 908). All 26 feral swine tested seronegative for pseudorabies, brucellosis, and IDVs (D/13N and D/46N).

We randomly separated the 26 feral swine into 3 groups: virus-inoculated animals $(\mathrm{n}=12)$, contact animals $(\mathrm{n}=8)$, and control animals $(\mathrm{n}=6)$. We used 12 pens to house the 26 feral swine; 4 pens contained 1 virus-inoculated animal plus 1 contact animal, 4 pens contained 2 virus-inoculated animals plus 1 contact animal, and 3 pens contained 2 control animals. Pens housing control feral swine were in an animal room separate from pens housing contact and inoculated feral swine. We inoculated each animal for the virus-inoculated group intranasally with $1 \mathrm{~mL}$ of $\mathrm{D} / 46 \mathrm{~N}\left(10^{6} 50 \%\right.$ tissue culture infective dose $\left.\left[\mathrm{TCID}_{50}\right]\right)$ and each control animal with $1 \mathrm{~mL}$ of phosphate-buffered saline. At 2 days postinoculation (dpi), we moved 1 contact animal into the pen housing 1 or 2 virus-inoculated feral swine. At $0,3,5,7,9,11$, and $21 \mathrm{dpi}$, we collected nasal washes, rectal swab samples, and blood from all animals. We stored nasal washes and rectal swab samples at $-80^{\circ} \mathrm{C}$ and serum samples at $-20^{\circ} \mathrm{C}$.

We euthanized feral swine at 3 dpi ( 1 virus-inoculated, 1 contact, and 1 control animal), 5 dpi (3 virus-inoculated, 1 contact, and 2 control animals), 7 dpi (3 virus-inoculated, 1 contact, and 1 control animal), 9 dpi (2 virus-inoculated, 1 contact, and 1 control animal), $11 \mathrm{dpi}$ ( 2 virus-inoculated and 1 contact animal), and 21 dpi (1 virus-inoculated, 3 contact, and 1 control animal). We collected nasal turbinate, soft palate, trachea, bronchi, and lung at necropsy and stored tissues at $-80^{\circ} \mathrm{C}$ before virologic characterization or fixed tissues in $10 \%$ neutral buffered formalin for histologic and immunohistochemical analysis.

\section{Calculation of TCID $_{50}$}

We serially diluted homogenate supernatants from tissue samples and nasal washes from $10^{-1}$ to $10^{-6}$ and titrated them in HRT-18G cells. We tested each sample in triplicate and calculated the TCID $_{50}$ by using the Reed-Muench method (27).

\section{Immunohistochemical Staining}

We performed IDV immunohistochemical staining as previously described (28). In brief, we heated slides at $65^{\circ} \mathrm{C}$ overnight. We deparaffinized and retrieved slides in an antigen retrieval solution at $\mathrm{pH} 6.1$ (Dako, Carpinteria, CA, USA) by using a decloaking chamber. We used Tris-buffered saline (TBS) with $0.5 \%$ Tween to wash slides and used $3 \% \mathrm{H}_{2} \mathrm{O}_{2}$ to quench peroxidase activity; we then blocked slides with 10\% normal goat serum (Invitrogen, Carlsbad,

\begin{tabular}{|c|c|c|c|c|c|}
\hline \multirow[b]{2}{*}{$\begin{array}{l}\text { Characteristic, no. } \\
\text { samples }\end{array}$} & \multicolumn{2}{|c|}{$\mathrm{D} / 13 \mathrm{~N}$} & \multicolumn{2}{|c|}{$\mathrm{D} / 46 \mathrm{~N}$} & \multirow[b]{2}{*}{$\begin{array}{c}\text { Total seropositive } \\
\text { swine, no. }(\%)\end{array}$} \\
\hline & $\begin{array}{c}\text { Seropositive swine, } \\
\text { no. (\%) }\end{array}$ & GMT (range) & $\begin{array}{c}\text { Seropositive swine, } \\
\text { no. }(\%)\end{array}$ & GMT (range) & \\
\hline \multicolumn{6}{|l|}{ Age } \\
\hline Juvenile, $n=32$ & 6 (18.8) & $63.5(1: 40-1: 160)$ & $1(3.1)$ & $80.0(1: 80-1: 80)$ & $7(21.9)$ \\
\hline Subadult, $n=43$ & $6(14.0)$ & $40.0(1: 40-1: 40)$ & $2(4.7)$ & $40.0(1: 40-1: 40)$ & $8(18.6)$ \\
\hline Adult, $\mathrm{n}=181$ & $27(14.9)$ & $65.1(1: 40-1: 160)$ & $15(8.3)$ & $58.8(1: 40-1: 160)$ & $34(18.8)$ \\
\hline \multicolumn{6}{|l|}{ Sex } \\
\hline$F, n=135$ & $23(17.0)$ & $62.9(1: 40-1: 160)$ & $10(7.4)$ & $54.0(1: 40-1: 160)$ & $28(20.7)$ \\
\hline$M, n=118$ & $16(13.6)$ & $56.6(1: 40-1: 160)$ & $8(6.8)$ & $61.7(1: 40-1: 160)$ & $21(17.8)$ \\
\hline
\end{tabular}


CA, USA) for $1 \mathrm{~h}$. We added bovine-generated antiserum to $\mathrm{D} / 46 \mathrm{~N}$ (diluted 1:200 in antibody diluent [Dako]) to the slides and incubated them at $-4^{\circ} \mathrm{C}$ for $24 \mathrm{~h}$. We then washed the slides with TBS with $0.5 \%$ Tween and incubated them for 30 min with biotinylated goat anti-bovine IgG polyclonal secondary antibody diluted 1:500 in TBS with $0.5 \%$ Tween. Slides were washed and then incubated with $\mathrm{ABC}$ reagent (Vectastain, Burlingame, $\mathrm{CA}$ ) according to the manufacturer's instructions, exposed to 3,3'-diaminobenzidine and $\mathrm{H}_{2} \mathrm{O}_{2}$ for $5 \mathrm{~min}$, counterstained with hematoxylin, and dehydrated; we then applied a coverslip.

\section{Biosafety and Animal Handling}

We conducted laboratory and animal experiments under Biosafety Level 2 conditions in compliance with protocols approved (QA 2563) by the Institutional Animal Care and Use Committee of the US Department of Agriculture's National Wildlife Research Center. Before necropsy, we fully anesthetized the feral swine with $0.044 \mathrm{~mL} / \mathrm{kg}$ TKX (Telazol 4.4 $\mathrm{mg} / \mathrm{kg}$, ketamine $2.2 \mathrm{mg} / \mathrm{kg}$, and xylazine $2.2 \mathrm{mg} / \mathrm{kg}$ ) and, once fully sedated, the swine were euthanized by administration of a barbiturate solution ( $1 \mathrm{~mL} / 4.5 \mathrm{~kg}$ body weight).

\section{Results}

To identify whether IDV is circulating among feral swine populations in the United States, we performed HAI against $\mathrm{D} / 46 \mathrm{~N}$ and $\mathrm{D} / 13 \mathrm{~N}$ on 256 serum samples from feral swine collected during October 1, 2012-September 30,2013 (11). We selected $\mathrm{D} / 46 \mathrm{~N}$ and $\mathrm{D} / 13 \mathrm{~N}$ to represent 2 genetic clades of IDVs, which are antigenically different $(13,29)$. Of the 256 samples, $39(15 \%)$ were positive for $\mathrm{D} / 13 \mathrm{~N}$ (HAI geometric mean titer [GMT] 60.2, range $1: 40-1: 160)$, and $18(7 \%)$ were positive for $\mathrm{D} / 46 \mathrm{~N}$ (HAI GMT 52.3, range 1:40-1:160); the overall seropositive rate was $19.1 \%$ for IDV. Of the 39 samples seropositive for $\mathrm{D} / 13 \mathrm{~N}, 8$ were also seropositive for $\mathrm{D} / 46 \mathrm{~N}$, but the other 31 samples were seronegative for $\mathrm{D} / 46 \mathrm{~N}$; of the 18 samples seropositive for $\mathrm{D} / 46 \mathrm{~N}, 10$ samples were also seropositive for $\mathrm{D} / 13 \mathrm{~N}$, whereas the other 8 samples were seronegative for $\mathrm{D} / 13 \mathrm{~N}$. These data suggest a greater prevalence of infection with viruses antigenically related to $\mathrm{D} / 13 \mathrm{~N}$ among the feral swine populations tested.

The overall seroprevalence rate for IDV (i.e., D/13N, $\mathrm{D} / 46 \mathrm{~N}$, or both) was $21.9 \%$ in juveniles $(\mathrm{n}=32), 18.6 \%$ in subadults $(\mathrm{n}=43)$, and $18.8 \%$ in adults $(\mathrm{n}=181)($ Table 2). Overall, seroprevalence was $17.8 \%$ among female feral swine $(\mathrm{n}=135)$ and $20.7 \%$ among male feral swine $(\mathrm{n}=$ 118) (Table 2). The sex of 3 feral swine was unknown, but the animals were seronegative for IDV. By state, IDV seropositive rates among feral swine were $20.5 \%$ in Hawaii, $7.8 \%$ in North Carolina, $28.6 \%$ in Oklahoma, and $21.4 \%$ in Texas (Table 1; online Technical Appendix Table 1, https:// wwwnc.cdc.gov/EID/article/24/6/17-2102-Techapp1.xlsx).
Previous serologic surveillance showed that $\approx 4.9 \%$ of feral swine had been exposed to IAVs (25). We explored whether an opportunity exists for feral swine to be exposed to both IAV and IDV. Our results show that $13(5.1 \%)$ of the 256 serum samples were IAV positive (Table 1,2), and $5(38.5 \%)$ of the 13 were IDV positive. To determine whether feral swine could have exposure to both IAV and IDV, we selected an additional 83 serum samples from the 294 IAV-positive samples collected during October 1, 2012-September 30, 2013. We tested the 96 IAV feral swine serum samples (including the 13 already discussed) against $\mathrm{D} / 46 \mathrm{~N}$ and $\mathrm{D} / 13 \mathrm{~N}$; of the 96 samples, $41(42.7 \%)$ were IDV seropositive for $\mathrm{D} / 13 \mathrm{~N}(\mathrm{n}=37$; GMT 1:59.6, range $1: 40-1: 160), \mathrm{D} / 46 \mathrm{~N}(\mathrm{n}=9$; GMT $1: 58.8$, range $1: 40$ $1: 160)$, or both ( $=5$; GMT1:59.3, range 1:40-1:160) (online Technical Appendix Table 2).

To evaluate the characteristics of IDV infection in feral swine, we inoculated $\mathrm{D} / 46 \mathrm{~N}$ virus intranasally into 12 feral swine. We chose $\mathrm{D} / 46 \mathrm{~N}$ because this virus was shown to cause infection and transmission as well as a substantial increase in neutrophil tracking in tracheal epithelia of the infected calves, and we intended to compare the pathogenesis in cattle with that in feral swine (28). The IDV-inoculated swine showed no clinical signs or changes in body temperature. Viral titration of nasal washes showed that, at $3 \mathrm{dpi}, 7$ of $12 \mathrm{D} / 46 \mathrm{~N}$-inoculated swine shed virus with a maximum titer of $2.199 \log _{10}$ TCID $_{50} / \mathrm{mL}$, and that, at $5 \mathrm{dpi}, 6$ of the 8 remaining virus-inoculated swine shed virus with a maximum titer of $2.366 \log _{10} \mathrm{TCID}_{50} / \mathrm{mL}$. None of the remaining 5 virusinoculated swine shed virus at or after $7 \mathrm{dpi}$ (Figure 2; online Technical Appendix Table 3). No virus was detected in any rectal swab samples from these experimentally infected feral swine.

HAI results indicated that $7(63.6 \%)$ of 11 virus-inoculated animals seroconverted at $5 \mathrm{dpi}$ and all 8 remaining virus-inoculated animals seroconverted at $7 \mathrm{dpi}$ (online Technical Appendix Table 4). We did not detect virus in any fecal swab samples from virus-inoculated swine, nor did we detect virus in nasal washes or fecal swab samples from the control feral swine, which remained seronegative throughout the study.

The viral titrations of feral swine tissues demonstrated viral replication in the upper and lower respiratory tract as well as the soft palate. At 5 dpi, viral titers were highest in the trachea sections $\left(2.699-2.366 \log _{10} \mathrm{TCID}_{50} / \mathrm{mL}\right)$ and lowest in the left and right caudal lung and soft palate (0.699-2.199 $\log _{10} \mathrm{TCID}_{50} / \mathrm{mL}_{0}$ ) (online Technical Appendix Table 3). At 7 dpi, we detected no virus in nasal swab samples; however, the highest (maximum) viral titer (3.866 $\log _{10} \mathrm{TCID}_{50} / \mathrm{mL}$ ) was in the soft palate, and the lowest viral titers $\left(0.699 \log _{10} \mathrm{TCID}_{50} / \mathrm{mL}\right)$ in the lower trachea (online Technical Appendix Table 3). 
Three of the 8 contact animals exposed to IDVinfected feral swine had detectable viral shedding: 1 animal shed virus at 5 days postexposure (titer $2.032 \log _{10}$ $\mathrm{TCID}_{50} / \mathrm{mL}$ ), and 1 animal each shed virus at 7 and 9 days
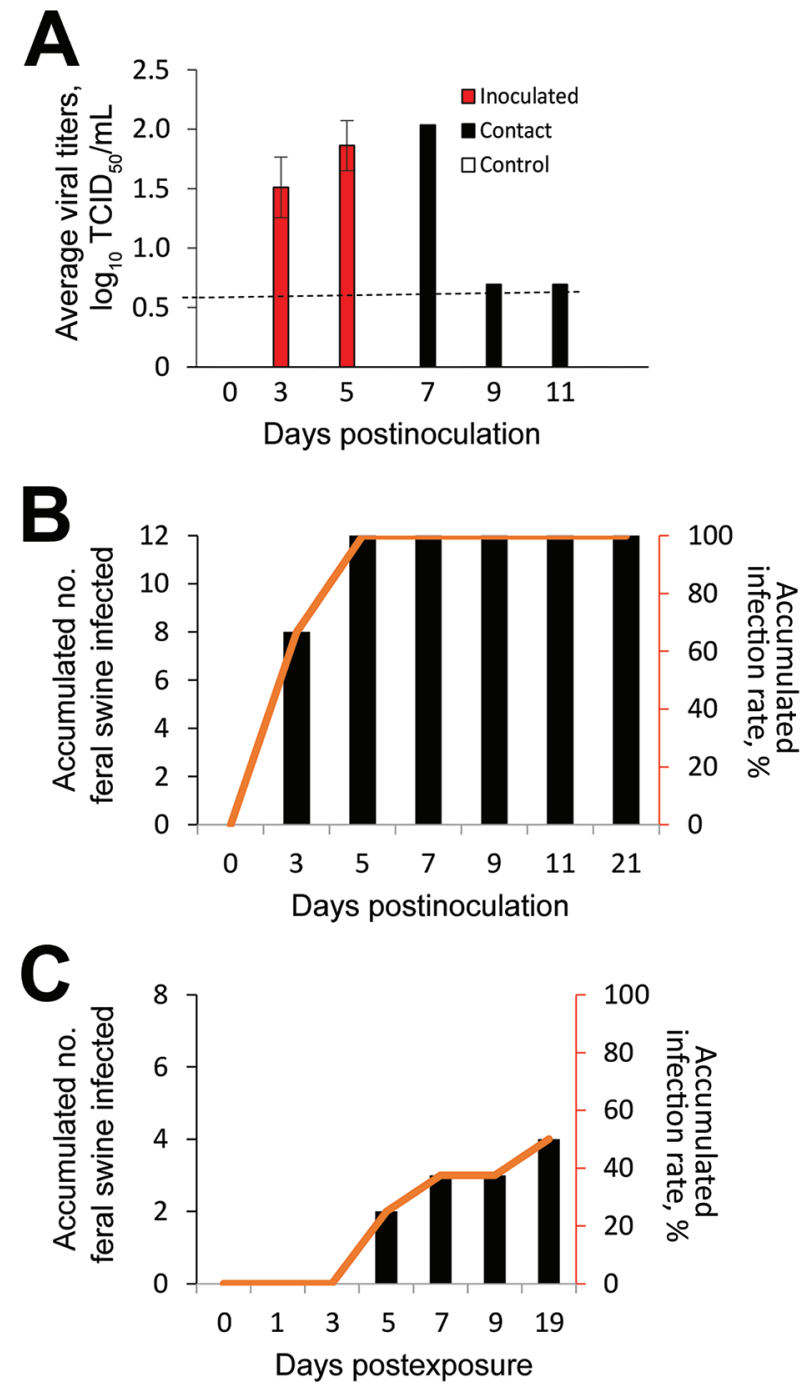

Figure 2. Infectivity and transmissibility of influenza D virus in feral swine populations, United States. A) Viral titers from nasal washes of feral swine. Feral swine were inoculated intranasally with $10^{6}$ $\mathrm{TCID}_{50} / \mathrm{mL}$ of influenza D/bovine/C00046N/Mississippi/2014 virus. Naive feral swine were exposed to the virus by direct contact with $D /$ bovine/C00046N/Mississippi/2014 virus-inoculated feral swine. On days $3,5,7,9$, and 11 after the inoculation group was inoculated, nasal washes were collected from all 3 groups of swine and in HRT-18G cells. Ending titers are expressed as $\log _{10} T C D_{50} / \mathrm{mL}$. The limit of virus detection was $10^{0.699} \mathrm{TCID}_{50} / \mathrm{mL}$. Error bars represent standard error of viral titers. The dashed line indicates the lower limit of detection, which is $10^{0.699} \mathrm{TCID}_{50} / \mathrm{mL}$. B) Accumulated number of feral swine infected and accumulated infection rate for the feral swine inoculated with influenza D virus. C) Accumulated number of feral swine infected and accumulated infection rate for the contact feral swine. A feral swine was considered infected if a viral titer was detected in nasal washes, serum samples, or both or if this feral swine seroconverted. $\mathrm{TCID}_{50}, 50 \%$ tissue culture infective dose. postexposure (both had a titer equal to the detection limit). At 19 days postexposure, 1 of the 3 remaining contact feral swine seroconverted, with an HAI titer of $1: 40$, indicating that IDV can be transmitted among feral swine (Table 3; online Technical Appendix Table 4). Nearly half of the contact animals exposed to IDV-infected feral swine were infected with IDV (Figure 2). We did not detect virus in any rectal swab samples from the contact feral swine. None of the contact animals showed any clinical signs or change in body temperature.

IDV causes viremia in IDV-inoculated feral swine and in feral swine that have direct contact with infected animals. Among the IDV-inoculated animals, we detected viremia in 3 animals (nos. 103, 105, and 125) at 3 dpi (titer $3.199 \log _{10} \mathrm{TCID}_{50} / \mathrm{mL}$ ) and in 1 animal (no. 125) at $5 \mathrm{dpi}$ (titer $2.199 \log _{10} \mathrm{TCID}_{50} / \mathrm{mL}$ ). Among the contact animals, we detected viremia in 1 animal (no. 118) at 7 days postexposure (titer $2.199 \log _{10} \mathrm{TCID}_{50} / \mathrm{mL}$ ) (online Technical Appendix Table 4).

Viral titration showed that virus was in the nasal turbinate, soft palate, trachea, lung tissues, or some combination of these tissues collected at 3-9 dpi. The tissue with the highest viral titer $\left(5.366 \log _{10} \mathrm{TCID}_{50} / \mathrm{mL}\right)$ was the lower trachea of an IDV-inoculated animal at 5 dpi. Immunohistochemical staining demonstrated the presence of IDV

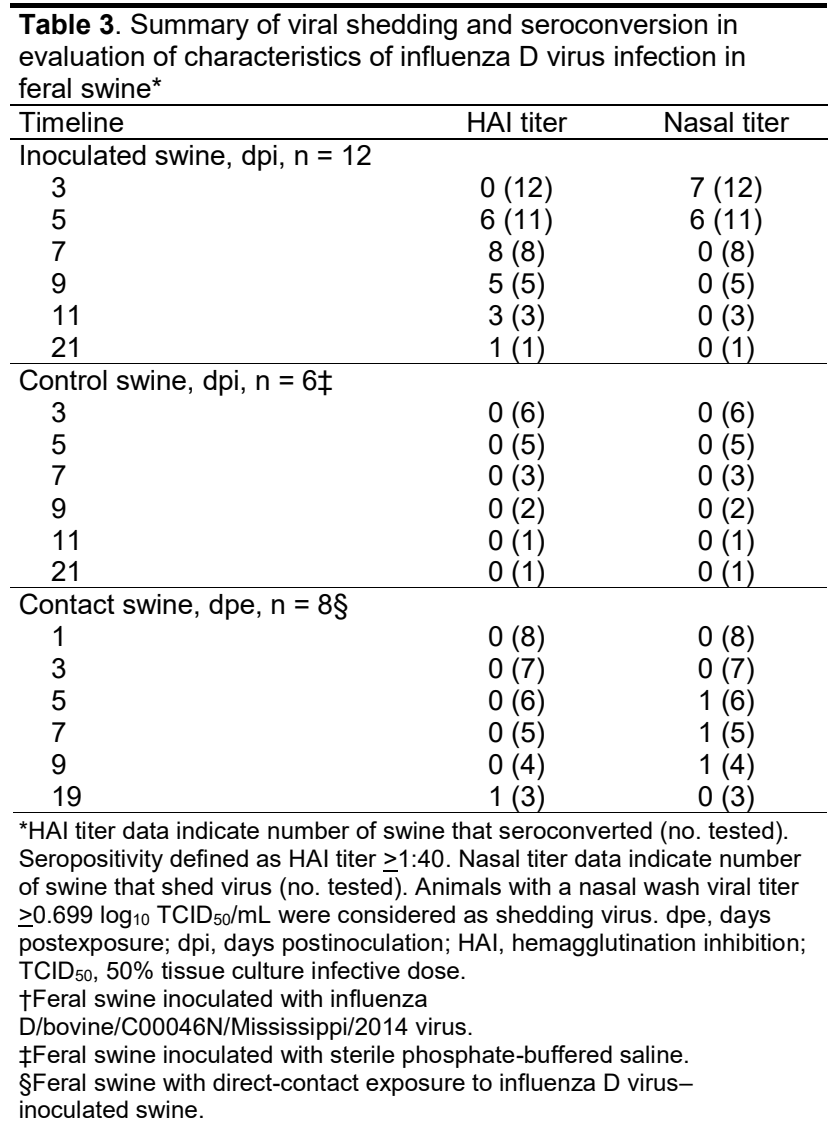


antigen in epithelial cells of the soft palate, trachea, and lung. In the lung, we observed IDV immunostaining in type I pneumocytes, macrophages, and bronchiolar epithelial cells (Figure 3 ). The viral titrations on tissues from contact animals indicated that they were negative for IDV.

\section{Discussion}

Since it was first identified in domestic swine in 2011, IDV has been detected in a wide range of animal hosts, mainly livestock such as bovids, goats, horses, and sheep, across multiple continents, indicating that IDV is a transboundary pathogen $(12-19,30)$. In the United States, feral swine serve as an important vector between domestic and wild animals for multiple transboundary diseases, such as Brucella suis and IAV (20-25). Our study demonstrated that the seroprevalence rate of IDV in feral swine was $19.1 \%$, which is similar to rates $(13.5 \%-18.3 \%)$ reported for commercial beef cattle (15) but higher than the reported rate $(<10 \%)$ in domestic swine (1). For example, a serologic study that used 220 pigs (3-20 weeks old) found that only $9.5 \%$ of tested domestic swine had an IDV titer $\geq 1: 10$, with a GMT of 1:20.7 (1). The difference in the seroprevalence between domestic and feral swine might be related to the fact that feral swine are mobile and have ample opportunities to come into contact with various domestic and wild animals; thus, compared with domestic swine, feral swine could have additional opportunities to be exposed to IDV. Among the 4 states that we sampled, the state with the highest IDV seroprevalence rate in feral swine also has the largest cattle population (Figure 1); however, whether IDV transmissions between bovids and feral swine is bidirectional is unknown. Two previous studies suggested that feral swine are likely to have indirect and direct contact with free-range bovine herds near water sources and that higher $B$. suis seroprevalence among free-range bovine herds was likely attributable to the bovine herd's close proximity to feral swine $(16,23)$. Nevertheless, the seroprevalence rate reported in our study among feral swine was based on convenience samples; thus, an epidemiologic study will be needed to determine the enzootic status of IDV in the feral swine population.

Previous studies have suggested that domestic swine are major sources of IAV exposure for feral swine $(24,25)$. IDV was shown not to cross-react with IAV (1), and our study showed that $42.3 \%$ of the IAV-seropositive feral swine had exposure to IDV, indicating that feral swine were exposed to both IDV and IAV. In addition, our results showed that the seroprevalence rate of IDV in IAVseropositive feral swine was more than twice that observed among IAV-negative feral swine. However, a larger epidemiologic study covering larger geographic areas and longer
Figure 3. Influenza D viral titers in feral swine tissues. Feral swine were inoculated intranasally with $10^{6} \mathrm{TCID}_{50}$ of influenza D/bovine/ C00046N/Mississippi/2014 virus or sterile phosphate-buffered saline (controls). At 3, 5, 7, 9, and 11 days postinoculation, they were humanely euthanized, and the following tissues were collected: turbinate; soft palate; upper, middle, and lower trachea; bronchus; left and right caudal lung; left and right medial lung; left and right cranial lung; and right accessory lung. A) The tissues were grouped as upper respiratory tract (turbinate and soft palate), trachea (upper, middle, and lower trachea, and bronchus), and lower respiratory tract (left and right caudal lung, left and right medial lung, and left and right cranial lung). B) All lung tissue sections at each time point that were influenza $D$ virus-positive by $\mathrm{TCID}_{50}$ titration in HRT-18G cells were averaged and plotted for each day postinoculation; day 9 has no error bars because only 1 positive tissue sample was found. Dashed lines indicate the lower limit of detection, which was $10^{0.699} \mathrm{TCID}_{50} / \mathrm{mL}$. Error bars indicate SE. Numbers in parentheses indicate number of animals used in the analyses. $\operatorname{TCID}_{50}, 50 \%$ tissue culture infective dose.
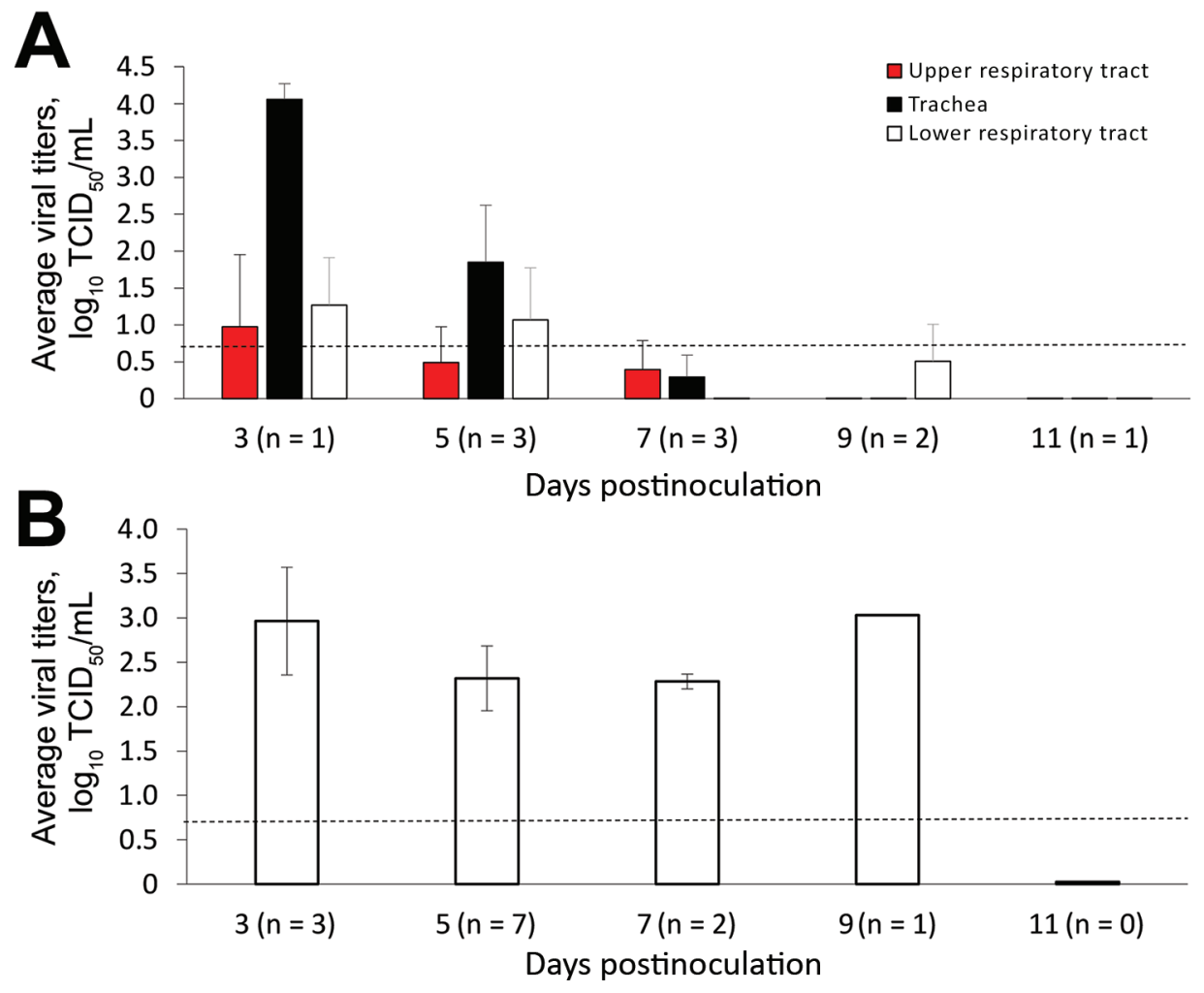
periods is needed to test the hypothesis that IDV would be more prevalent in IAV-positive than IAV-negative feral swine. The effect of IDV infections on the pathogenesis of $\mathrm{IAV}$, or vice versa, remains unknown, but findings from our study and previous studies suggest that future work ought to focus on whether feral swine act as a vector for transboundary disease between domestic swine and cattle.

The results of our animal challenge study show that IDV can be transmitted among feral swine; however, the infection resulted in limited clinical signs. Cattle infected with IDV shed virus up to $9 \mathrm{dpi}$, with a peak titer of 4.417 $\log _{10} \mathrm{TCID}_{50} / \mathrm{mL}$ (28), whereas the swine infected with IDV in our study shed virus only up to $5 \mathrm{dpi}$, with a peak titer of $2.366 \log _{10} \mathrm{TCID}_{50} / \mathrm{mL}$ (Figure 2). Such a difference might be attributable to the distinct patterns of viral distributions in the respiratory tracts of the infected animals. In cattle, IDV was predominantly distributed in the tissues of the upper respiratory tract (i.e., turbinate and trachea) (28), but in swine the distribution was predominantly in the middle and lower respiratory tract (i.e., trachea and lung) (Figure 4, panel A). Previous studies have suggested that, under laboratory conditions, IDV replicates in the upper and lower respiratory tracts of guinea pigs infected with a bovine strain of IDV ( 6 ). In addition, bovine IDV infects ferrets and can be transmitted to IDV-naive ferrets through direct contact; however, IDV cannot infect naive ferrets through a fomite contaminated with nasal drainage from IDV-infected calves $(1,28)$. Another swine infection study indicated that no viruses were detected in the lung of domestic swine that were infected with $\mathrm{D} /$ swine/Oklahoma/1334/2011 (1). The genetic variations between $\mathrm{D} /$ swine/Oklahoma/1334/2011 and D/46N used in these studies might have led to the difference in viral tissue tropisms observed in these 2 studies.

Three IDV-inoculated animals and 1 contact animal in our study had transient viremia, a finding consistent with a previous study that found IDV in animal serum samples during IDV surveillance (31). We found IDV at moderate viral titers in the soft palate of feral swine at $3 \mathrm{dpi}$, and the viremia lasted $\geq 3$ days for some animals (online Technical Appendix Table 3). The soft palate has been identified as a major site of influenza virus infection in ferrets (32). Previous studies have shown that several bacteria (e.g., Streptococcus porcinus, Streptococcus dysgalactiae,

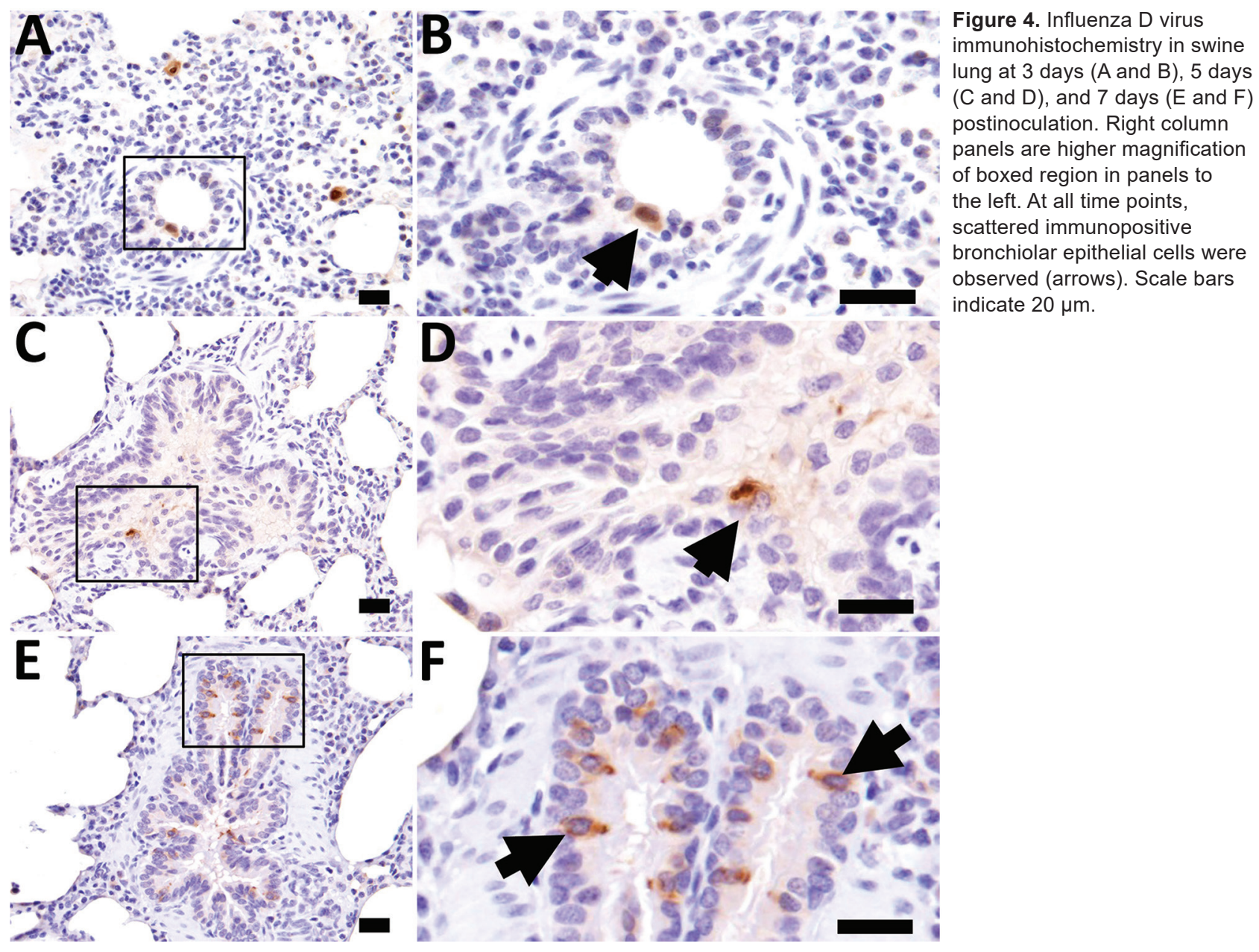


Staphylococcus aureus, Staphylococcus hyicus, Streptococcus suis, Yersinia enterocolitica, Salmonella spp., and Listeria monocytogenes) and viruses (e.g., porcine reproductive and respiratory syndrome virus and porcine circovirus-2) can be isolated from the soft palate (33). The rich distribution of lymphoid tissue in the soft palate might enable virus from the soft palate to enter the bloodstream and cause the transient viremia observed in feral swine that we observed in the experimentally infected feral swine.

The transmission ability of IDV through direct contact is similar to that in domestic swine; however, the transmission ability in feral and domestic swine seems to be less efficient than that in bovids, as suggested by viral load titers and durations of shedding $(1,28)$. Given the limited transmissibility of IDV in feral swine, we would speculate that feral swine could have additional opportunities for exposure to IDV in addition to IDVs circulating in the feral swine populations.

In summary, our findings suggest that IDV has been circulating in the feral swine population across multiple states in the United States and that IDV can be transmitted among feral swine. Although the economic impact of IDV on commercial livestock remains unknown, our findings suggest that feral swine might be important in the ecology of IDV. Further studies are needed to understand whether other wild animals are infected by IDV and to what extent interspecies transmission contributes to IDV maintenance in domestic and wild populations.

\section{Acknowledgments}

We thank Charles Provine, Karen Nyguen, and Brigitte Martin for their assistance with this project.

This study was supported by the US Department of Agriculture's Animal and Plant Health Inspection Service (grant no. 15-729-1146CA) and partially funded by the National Institutes of Health's National Institute of Allergy and Infectious Diseases (grant no. 1R15AI107702A-01).

\section{About the Author}

Mr. Ferguson graduated in May 2017 with a B.S. in biochemistry and molecular biology from Mississippi State University, where his research focused on the epidemiology and pathology of influenza D viruses. He is currently a graduate student at the University of Cambridge as a Gates Cambridge Scholar.

\section{References}

1. Hause BM, Ducatez M, Collin EA, Ran Z, Liu R, Sheng Z, et al. Isolation of a novel swine influenza virus from Oklahoma in 2011 which is distantly related to human influenza $\mathrm{C}$ viruses. PLoS Pathog. 2013;9:e1003176. http://dx.doi.org/10.1371/journal.ppat.1003176

2. Song H, Qi J, Khedri Z, Diaz S, Yu H, Chen X, et al. an open receptor-binding cavity of hemagglutinin-esterase-fusion glycoprotein from newly-identified influenza $\mathrm{D}$ virus: basis for its broad cell tropism. PLoS Pathog. 2016;12:e1005411. http://dx.doi.org/10.1371/journal.ppat.1005411
3. Hause BM, Collin EA, Liu R, Huang B, Sheng Z, Lu W, et al. Characterization of a novel influenza virus in cattle and swine: proposal for a new genus in the Orthomyxoviridae family. mBiol 2014;5:e00031-14.

4. Jiang W-M, Wang S-C, Peng C, Yu J-M, Zhuang Q-Y, Hou G-Y, et al. Identification of a potential novel type of influenza virus in Bovine in China. Virus Genes. 2014;49:493-6. http://dx.doi.org/ 10.1007/s11262-014-1107-3

5. Ducatez MF, Pelletier C, Meyer G. Influenza D virus in cattle, France, 2011-2014. Emerg Infect Dis. 2015;21:368-71. http://dx.doi.org/10.3201/eid2102.141449

6. Sreenivasan C, Thomas M, Sheng Z, Hause BM, Collin EA, Knudsen DEB, et al. Replication and transmission of the novel bovine influenza D virus in a Guinea pig model. J Virol. 2015;89:11990-2001. http://dx.doi.org/10.1128/JVI.01630-15

7. Chiapponi C, Faccini S, De Mattia A, Baioni L, Barbieri I, Rosignoli C, et al. Detection of influenza D virus among swine and cattle, Italy. Emerg Infect Dis. 2016;22:352-4. http://dx.doi.org/10.3201/eid2202.151439

8. Foni E, Chiapponi C, Faccini S, Baioni L, Barbieri I, Rosignoli C, et al. The circulation of influenza $D$ in pig breeding farms of northern Italy. Proceedings of the Italian Society of Pathology and Breeding of Pigs, XLII Annual Meeting, Montichiari, Italia, March 10-11, 2016. 2016:151-5.

9. Horimoto T, Hiono T, Mekata H, Odagiri T, Lei Z, Kobayashi T, et al. Nationwide distribution of bovine influenza $D$ virus infection in Japan. PLoS One. 2016;11:e0163828. http://dx.doi.org/10.1371/ journal.pone. 0163828

10. Murakami S, Endoh M, Kobayashi T, Takenaka-Uema A, Chambers JK, Uchida K, et al. Influenza D virus infection in herd of cattle, Japan. Emerg Infect Dis. 2016;22:1517-9. http://dx.doi.org/10.3201/eid2208.160362

11. Foni E, Chiapponi C, Baioni L, Zanni I, Merenda M, Rosignoli C, et al. Influenza D in Italy: towards a better understanding of an emerging viral infection in swine. Sci Rep. 2017;7:11660. http://dx.doi.org/10.1038/s41598-017-12012-3

12. Quast M, Sreenivasan C, Sexton G, Nedland H, Singrey A, Fawcett L, et al. Serological evidence for the presence of influenza D virus in small ruminants. Vet Microbiol. 2015;180:281-5. http://dx.doi.org/10.1016/j.vetmic.2015.09.005

13. Luo J, Ferguson L, Smith DR, Woolums AR, Epperson WB, Wan XF. Serological evidence for high prevalence of Influenza D Viruses in Cattle, Nebraska, United States, 2003-2004. Virology. 2017;501:88-91. http://dx.doi.org/10.1016/j.virol.2016.11.004

14. Ducatez MF, Pelletier C, Meyer G. Influenza D virus in cattle, France, 2011-2014. Emerg Infect Dis. 2015;21:368-71. http://dx.doi.org/10.3201/eid2102.141449

15. Ferguson L, Eckard L, Epperson WB, Long LP, Smith D, Huston C, et al. Influenza D virus infection in Mississippi beef cattle. Virology. 2015;486:28-34. http://dx.doi.org/10.1016/j.virol.2015.08.030

16. Cooper SM, Scott HM, de la Garza GR, Deck AL, Cathey JC. Distribution and interspecies contact of feral swine and cattle on rangeland in south Texas: implications for disease transmission. J Wildl Dis. 2010;46:152-64. http://dx.doi.org/10.7589/0090-3558-46.1.152

17. Wyckoff AC, Henke SE, Campbell TA, Hewitt DG, VerCauteren KC. Feral swine contact with domestic swine: a serologic survey and assessment of potential for disease transmission. J Wildl Dis. 2009;45:422-9. http://dx.doi.org/10.7589/0090-3558-45.2.422

18. Gipson PS, Hlavachick B, Berger T, Lee CD. Explanations for recent range expansions by wild hogs into Midwestern states. Proceedings of Great Plains Wildlife Damage Control Workshop 13, 1997. Manhattan (KS, USA): Kansas State University Agricultural Experiment Station and Cooperative Extension Service; 1997. p. 148-50.

19. Fogarty EP. National distribution of and stakeholder attitudes toward feral hogs. Mississippi State (MS, USA): Mississippi State University; 2007. 
20. Hall JS, Minnis RB, Campbell TA, Barras S, Deyoung RW, Pabilonia K, et al. Influenza exposure in United States feral swine populations. J Wildl Dis. 2008;44:362-8. http://dx.doi.org/ 10.7589/0090-3558-44.2.362

21. Corn JL, Cumbee JC, Barfoot R, Erickson GA. Pathogen exposure in feral swine populations geographically associated with high densities of transitional swine premises and commercial swine production. J Wildl Dis. 2009;45:713-21. http://dx.doi.org/ 10.7589/0090-3558-45.3.713

22. Clavijo A, Nikooienejad A, Esfahani MS, Metz RP, Schwartz S, Atashpaz-Gargari E, et al. Identification and analysis of the first 2009 pandemic H1N1 influenza virus from U.S. feral swine. Zoonoses Public Health. 2013;60:327-35. http://dx.doi.org/ 10.1111/zph.12006

23. Musser JM, Schwartz AL, Srinath I, Waldrup KA. Use of serology and bacterial culture to determine prevalence of Brucella spp. in feral swine (Sus scrofa) in proximity to a beef cattle herd positive for Brucella suis and Brucella abortus. J Wildl Dis. 2013;49:21520. http://dx.doi.org/10.7589/2012-06-169

24. Feng Z, Baroch JA, Long L-P, Xu Y, Cunningham FL, Pedersen K, et al. Influenza A subtype H3 viruses in feral swine, United States, 2011-2012. Emerg Infect Dis. 2014;20:843-6. http://dx.doi.org/ 10.3201/eid2005.131578

25. Martin BE, Sun H, Carrel M, Cunningham FL, Baroch JA, Hanson-Dorr KC, et al. Feral swine in the United States have been exposed to both avian and swine influenza A viruses. Appl Environ Microbiol. 2017;83:e01346-17. http://dx.doi.org/10.1128/AEM.01346-17

26. Bevins SN, Pedersen K, Lutman MW, Gidlewski T, Deliberto TJ. Consequences associated with the recent range expansion of nonnative feral swine. Bioscience. 2014;64:291-9. http://dx.doi.org/10.1093/biosci/biu015

27. Reed LJ, Muench H. Muench. H. A simple method of estimating fifty percent endpoints. Am J Epidemiol. 1938;27:5. http://dx.doi.org/10.1093/oxfordjournals.aje.a118408
28. Ferguson L, Olivier AK, Genova S, Epperson WB, Smith DR, Schneider L, et al. Pathogenesis of influenza D virus in cattle. J Virol. 2016;90:5636-42. http://dx.doi.org/10.1128/ JVI.03122-15

29 Collin EA, Sheng Z, Lang Y, Ma W, Hause BM, Li F.

Cocirculation of two distinct genetic and antigenic lineages of proposed influenza D virus in cattle. J Virol. 2015;89:1036-42. http://dx.doi.org/10.1128/JVI.02718-14

30. Nedland H, Wollman J, Sreenivasan C, Quast M, Singrey A, Fawcett L, et al. Serological evidence for the co-circulation of two lineages of influenza $\mathrm{D}$ viruses in equine populations of the Midwest United States. Zoonoses Public Health. 2018;65:e148-54. http://dx.doi.org/10.1111/zph.12423

31. Zhai SL, Zhang H, Chen SN, Zhou X, Lin T, Liu R, et al. Influenza $D$ virus in animal species in Guangdong Province, southern China. Emerg Infect Dis. 2017;23:1392-6. http://dx.doi.org/10.3201/ eid2308.170059

32. Lakdawala SS, Jayaraman A, Halpin RA, Lamirande EW, Shih AR, Stockwell TB, et al. The soft palate is an important site of adaptation for transmissible influenza viruses. Nature. 2015; 526:122-5. http://dx.doi.org/10.1038/ nature 15379

33. Kernaghan S, Bujold AR, MacInnes JI. The microbiome of the soft palate of swine. Anim Health Res Rev. 2012;13:110-20. http://dx.doi.org/10.1017/S1466252312000102

Address for correspondence: Fred L. Cunningham, USDA/APHIS/WS/ NWRC, Mississippi Field Station, PO Box 6099, Mississippi State, MS 39762, USA; email: fred.l.cunningham@aphis.usda.gov; Xiu-Feng Wan, Mississippi State University, College of Veterinary Medicine, Department of Basic Science, 240 Wise Center Dr, Starkville, MS 39762, USA; email: wan@crm.msstate.edu

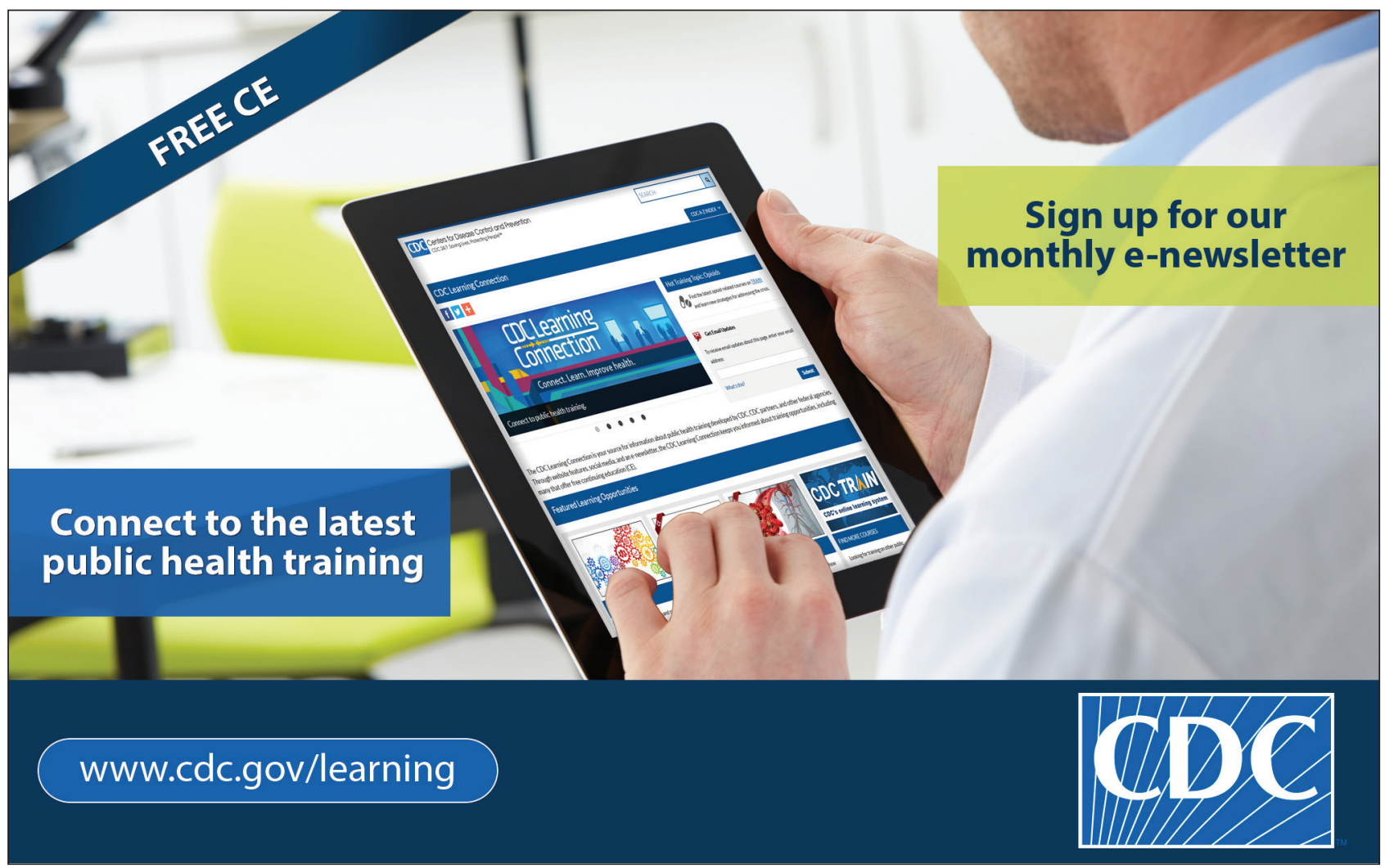

